\title{
Studies on the Microbiological Determination of Niacin in Some Marine Algae
}

\author{
ARNE E. BOLINDER and BJØRN LARSEN
}

Division of Food Chemistry, Royal Institute of Technology, Stockholm 70, Sweden, and Norwegian Institute of Seaweed Research, N.T.H., Trondheim, Norway

1. The microbiological determination of niacin in marine algae has been carried out with three different test organisms: Streptococcus faecalis ATCC 8043, Lactobacillus arabinosus ATCC 8014, and Lactobacillus casei ATCC 7469. A single basal medium, with minor changes, was used for the three test organisms.

2. A cup plate assay method for niacin with $S$. faecalis as the test organism is described in detail. In the concentration range of 0.05 to $100 \mu \mathrm{g}$ of niacin per $\mathrm{ml}$, well defined zones of dense growth were obtained.

3. Comparative assays for niacin on eight selected algal samples were carried out in both laboratories using the cup plate method with $S$. faecalis and also the turbidimetric tube assay method with $S$. faecalis and $L b$. arabinosus. The most favourable conditions for the extraction of niacin were determined. Recovery tests with added niacin were also performed.

The highest niacin assay values were obtained by hydrolysing the samples with $\mathrm{N}$ sulfuric acid for $1 \mathrm{~h}$ at $120^{\circ} \mathrm{C}$ and assaying by the $L b$. arabinosus tube method. For the purpose of screening a large number of algal samples, hydrolysing with $3 \mathrm{~N}$ sulfuric acid at $120^{\circ} \mathrm{C}$ for $1 \mathrm{~h}$ and assaying by the $S$. faecalis cup plate method is recommended. This assay method generally gives $0-20 \%$ lower niacin assay values than the $L b$. arabinosus tube method.

4. Bioautography of extracts of the eight selected algal samples was made with $L b$. arabinosus plates. In extracts prepared by hydrolysing with $\mathrm{N}$ or $3 \mathrm{~N}$ sulfuric acid, only niacin was found. However, in extracts prepared by hydrolysing with $0.1 \mathrm{~N}$ sulfuric acid, niacinamide was predominant while niacin was either absent or found only in trace amounts.

5. A simple method for the bioautographic detection of "bound" niacin (an alkali-labile complex containing niacin) was developed. Bioautographic tests for the presence of "bound" niacin in the algal samples were negative.

6. Comparative assays for niacin on another set of selected algal samples were carried out by the turbidimetric tube assay method with $L b$. arabinosus, $L b$. casei and $S$. faecalis. The results with $L b$. arabi. nosus and $L b$. casei agreed very well although the former test organism in some cases gave slightly higher assay values than the latter. The $S$. faecalis tube method gave considerably lower niacin assay values. 
Numerous reports have been published on the determination of niacin in 1 various natural materials. However, the only report concerning the determination of niacin in marine algae has been published by Ericson ${ }^{1}$. His determinations were made microbiologically by the cup plate method using Lactobacillus arabinosus ATCC 8014 as the test organism. Apart from testing several extraction procedures for the liberation of niacin, no attempt was made to ascertain the validity or accuracy of the assay method used, e.g. by recovery tests, comparative assays with the tube method or assays with other test organisms.

The most commonly used assay method for the microbiological determination of niacin is the tube assay method with $L b$. arabinosus as the test organism ${ }^{2-8}$, the response of which is measured either turbidimetrically or by titration of the acid produced. Other organisms have also been used for the tube assay of niacin (cf. Ref. ${ }^{3}$ ), notably lactobacilli, e.g. Lactobacillus casei ${ }^{9-13}$ and Leuconostoc mesenteroides ${ }^{14-16}$, but these methods have not been investigated so thoroughly as the assay with $L b$. arabinosus. Microbiological assays for niacin by the plate assay method with $L b$. arabinosus as the test organism have also been published ${ }^{1,17-25}$. Compared to the tube method, the plate assay method is simpler to carry out and less time-consuming, although the sensitivity is lower ${ }^{26,27}$. The plate assay method is particularily suitable when a great number of samples are to be assayed.

This paper deals with the comparative assays for niacin in marine algae carried out by several assay methods. The most favourable conditions for the extraction of niacin from algae were investigated and bioautographic studies were made. Values for the niacin contents of marine algae obtained by utilizing the assay procedures given in this paper have already been published 28,29 .

\section{EXPERIMENTAL*}

Samples. Eight different samples of marine algae from the Norwegian coast were selected for a collaborative investigation on comparative assays for niacin carried out according to the cup plate method with $S$. faecalis and the turbidimetric tube assay method with $L b$, arabinosus and $S$. faecalis. The species used are listed in Table 1 together with habitat and date of harvest for each sample. In a separate investigation, where the turbidimetric tube assay methods for niacin with $S$. faecalis, Lb. arabinosus and $L b$. casei were compared, another set of algal samples was used (see Table 8).

Each algal sample consisted of at least fifty plants. After drying at room temperature, the samples were ground in a Wiley laboratory mill and stored in air-tight tins. A sample of wheat bran was used as a source of "bound" niacin. It was purchased in a local store and ground in a. Wiley laboratory mill.

All niacin assay values are given as $\mu \mathrm{g}$ per $\mathrm{g}$ dry weight of sample.

Preparation of extracts. Extraction of the algal samples for niacin assays was carried out with $\mathrm{N}$ or $3 \mathrm{~N}$ sulfuric acid. The following procedure was used: $1 \mathrm{~g}$ of dried sample was throughly mixed with $15 \mathrm{ml}$ sulfuric acid $(\mathrm{N}$ or $3 \mathrm{~N})$ in a small beaker covered with aluminium foil and the mixture was autoclaved for $1 \mathrm{~h}$ at $120^{\circ} \mathrm{C}$. After cooling, $3 \mathrm{ml}$ sodium hydroxide $(5 \mathrm{~N}$ or $15 \mathrm{~N}$ ) was added. After cooling once again, the $\mathrm{pH}$ of the mixture was adjusted to $6.7 \pm 0.2$ with sulfuric acid or sodium hydroxide. The slurry was transferred quantitatively to a volumetric flask and diluted with distilled water to

* If not otherwise stated in the text, exactly the same experimental procedures were used in laboratory I (Division of Food Chemistry, Stockholm) and laboratory II (Norwegian Institute of Seaweed Research, N.T.H., Trondheim). 
Table 1. Algal samples selected for the collaborative investigation of assay methods for niacin.

\begin{tabular}{|c|c|c|c|}
\hline Algae & Sample & Locality & Date of harvest \\
\hline $\begin{array}{l}\text { Ascophyllum nodosum } \\
\text { " } \\
\text { Fucus serratus " } \\
\text { " " } \\
\text { Laminaria "hyperborea } \\
\text { " " " " }\end{array}$ & $\begin{array}{ll}\text { An } & 1 \\
\text { An } & 2 \\
\text { Fs } & 1 \\
\text { Fs } & 2 \\
\text { Lh } & 1 \\
\text { Lh } & 2 \\
\text { Rp } & 1 \\
\text { Rp } & 2\end{array}$ & $\begin{array}{c}\text { Reine } \\
\text { Trondheimsfjord } \\
\text { Reine } \\
\text { Trondheimsfjord } \\
\text { " }\end{array}$ & $\begin{array}{r}27.2 .1956 \\
30.8 .1956 \\
19.3 .1956 \\
10.8 .1956 \\
25.2 .1955 \\
22.8 .1955 \\
7.2 .1955 \\
25.4 .1955\end{array}$ \\
\hline
\end{tabular}

Table 2. Composition of assay media used for the microbiological assay of niacin. The amounts refer to $500 \mathrm{ml}$ double strength medium. The $\mathrm{pH}$ of each medium was adjusted to 6.5 .

\section{Component}

Bacto vitamin free casamino acids (Difco) Sodium acetate $(3 \mathrm{aq})$ Trisodium citrate ( $2 \mathrm{aq})$ Glucose

DL-Alanine L-Asparagine L-Cysteine hydrochloride L.-Cystine hydrochloride DL-Tryptophan

Adenine sulfate Guanine hydrochloride Uracil

Xanthine

Thiamine hydrochloride

Riboflavin

Calcium pantothenate Pyridoxine hydrochloride Pyridoxal hydrochloride Pyridoxamine dihydrochloride $p$-Aminobenzoic acid Biotin

Folic acid

Dipotassium phosphate

Sodium chloride

Ammonium sulfate

Magnesium sulfate (7 aq)

Manganese sulfate (4 aq)

Ferrous sulfate $(7 \mathrm{aq})$

Tween 80 (Atlas)
Acetate medium

$$
\begin{array}{r}
5 \mathrm{~g} \\
20 \mathrm{~g} \\
20 \mathrm{~g}
\end{array}
$$

$100 \mathrm{mg}$

$100 \mathrm{mg}$

$100 \mathrm{mg}$

$100 \mathrm{mg}$

$200 \mathrm{mg}$

$10 \mathrm{mg}$

$10 \mathrm{mg}$

$10 \mathrm{mg}$

$10 \mathrm{mg}$

$1 \mathrm{mg}$

$1 \mathrm{mg}$

$1 \mathrm{mg}$

$1 \mathrm{mg}$

$1 \mathrm{mg}$

$1 \mathrm{mg}$

$500 \mu \mathrm{g}$

$20 \mu \mathrm{g}$

$20 \mu \mathrm{g}$

\section{$1 \mathrm{~g}$ \\ $1 \mathrm{~g}$ \\ $1 \mathrm{~g}$}

$100 \mathrm{mg}$

$30 \mathrm{mg}$

$10 \mathrm{mg}$

$0.5 \mathrm{ml}$
Citrate medium

$$
\begin{array}{rr}
5 & \mathrm{~g} \\
1 \mathrm{~g} \\
20 \mathrm{~g} \\
20 \mathrm{~g}
\end{array}
$$

$$
100 \mathrm{mg}
$$

$100 \mathrm{mg}$ $100 \mathrm{mg}$ $100 \mathrm{mg}$ $200 \mathrm{mg}$

$10 \mathrm{mg}$

$10 \mathrm{mg}$

$10 \mathrm{mg}$

$10 \mathrm{mg}$

$1 \mathrm{mg}$

$1 \mathrm{mg}$

$1 \mathrm{mg}$

$1 \mathrm{mg}$

$1 \mathrm{mg}$

$1 \mathrm{mg}$

$500 \mu \mathrm{g}$

$20 \mu \mathrm{g}$

$20 \mu \mathrm{g}$

$$
\begin{array}{ll}
3 & \mathrm{~g} \\
1 & \mathrm{~g} \\
\mathrm{l} & \mathrm{g}
\end{array}
$$

$500 \mathrm{mg}$ $150 \mathrm{mg}$ $50 \mathrm{mg}$

$0.5 \mathrm{ml}$

Acta Chem. Scand. 15 (1961) No. 4 
$25 \mathrm{ml}$ (laboratory II) or to $50 \mathrm{ml}$ (laboratory I). After centrifuging, the supernatant was stored in small flasks at $-20^{\circ} \mathrm{C}$.

Extracts used for bioautography were prepared by autoclaving $1 \mathrm{~g}$ of dried algal sample with $15 \mathrm{ml} 0.1 \mathrm{~N}$ sulfuric acid for $30 \mathrm{~min}$ at $120^{\circ} \mathrm{C}$. After cooling, the $\mathrm{pH}$ was adjusted to $6.7 \pm 0.2$ and the slurry centrifuged. The supernatant was stored at $-20^{\circ} \mathrm{C}$.

Test organisms. Stab cultures of Streptococcus faecalis ATCC 8043, Lb. arabinosus ATCC 8014, Lb. casei ATCC 7469, Lb. fermenti ATCC 9338 and Leuconostoc mesenteroides ATCC 9135 were maintained on Bacto micro assay culture agar (Difco)*. The organisms were transferred at least once every month. After incubation overnight at $37^{\circ} \mathrm{C}$, the cultures were stored in a refrigerator.

Measurement of bacterial growth in the tubes. For the standardization of the inocula used for the plate and the tube assays, as well as for the measurement of the bacterial growth in the tube assays, turbidimetric measurements were made at $640 \mathrm{~m} \mu$ and expres. sed as percent light transmittance. The measurements in laboratory I were made with optically calibrated rimless test tubes $(19 \times 180 \mathrm{~mm})$ in a Coleman Model 11 Universal spectrophotometer and in laboratory II with optically calibrated rimless test tubes (16 $\times$ $150 \mathrm{~mm}$ ) in a Unicam Model DG spectrophotometer. Since test tubes of larger diameter were used in laboratory I, the same bacterial suspension will give a lower reading for percent light transmittance in laboratory $I$ than in laboratory II.

Assay media. One single basal medium, with minor changes, was used in the assays for niacin with the different test organisms. Two variants of this basal medium, the acetate medium and the citrate medium, were used and the composition of these media is given in Table 2. These basal media have the same general composition as the commonly used B-vitamin assay media recommended for lactobacilli. ${ }^{3-5}$ Adjustment of the $\mathrm{pH}$ of the media was made with sodium hydroxide or sulfuric acid. The acetate medium was used for the assays with $L b$. arabinosus and $L b$. casei (and for the preliminary cup plate tests with $L b$. fermenti and $L$. mesenteroides) and the citrate medium for the assays with $S$. faecalis. Solutions of the components of the assay media were made according to procedures published earlier. ${ }^{2-8}$ All chemicals used for preparing the media were of at least "puriss" quality in laboratory I and mostly of "analytical grade" in laboratory II. Distilled water from a commercial laboratory scale metal distillation apparatus was used for all work in both laboratories. The unsterilized double strength media were stored at $-20^{\circ} \mathrm{C}$. Media stored for 3-4 months have been successfully used.

Inoculum media. Bacto inoculum broth (Difco) was used as the inoculum medium for $S$. faecalis. However, this inoculum medium was not satisfactory for obtaining a good and rapid growth of the other test organisms. We therefore also used a fortified Bacto micro inoculum broth, the composition of which is given in Table 3. This inoculum medium promoted a rapid growth of the remaining test organisms as well as of other test organisms commonly used for microbiological assays, e.g. Lb. acidophilus, Lb. leichmannii and Pediococcus cerevisiae (Leuconostoc citrovorum).

Centrifuge tubes $(16 \times 110 \mathrm{~mm})$ were filled with $5 \mathrm{ml}$ portions of inoculum medium and a glass bead was added to each tube. The cotton-plugged tubes were sterilized for $15 \mathrm{~min}$ at $120^{\circ} \mathrm{C}$.

Preparation of inocula. Broth subcultures were incubated at $37^{\circ} \mathrm{C}$, in laboratory I for $10-12 \mathrm{~h}$ and in laboratory II for $16-20 \mathrm{~h}$. To prepare the inocula, the subcultures were centrifuged, washed two times with $5 \mathrm{ml}$ portions of sterile $0.9 \%$ sodium chloride solu-

* Difco Laboratories, Inc., Detroit, Michigan, USA.

Table 3. Composition of the fortified Bacto micro inoculum broth (Difco). The amounts refer to $1000 \mathrm{ml}$ single strength medium.

Bacto micro inoculum broth (Difco)

Double strength acetate medium ${ }^{\mathrm{a}}$

Niacin

Leucovorin (synthetic folinic acid)

Vitamin $\mathrm{B}_{\mathbf{1 2}}$
$37 \mathrm{~g}$

$10 \mathrm{ml}$

$20 \mu \mathrm{g}$

$0.5 \mu \mathrm{g}$

$0.05 \mu \mathrm{g}$

a See Table 2 for composition. 
tion, and then resuspended and diluted with sterile $0.9 \%$ sodium chloride solution to the desired turbidity. When adjusting the inocula, a tube containing distilled water and set at $100 \%$ transmittance was used as the blank.

For making plates with the test organisms, $5 \mathrm{ml}$ of an inoculum with a light transmittance of $50 \%$ was used for each plate. Since the instruments and tubes for adjusting the inocula were different in the two laboratories, this inoculum density corresponds in laboratory I to $60-80 \mu \mathrm{g}$ and in laboratory II to $220-280 \mu \mathrm{g}$ dry weight of cell material per $\mathrm{ml}$ inoculum.

For the tube assays, a dilute inosulum was employed. One ml of a washed cell suspension of each test organism having a light transmittance of $50 \%$ was mixed with $50 \mathrm{ml}$ sterile sodium chloride solution and, after shaking thoroughly, two drops of this dilute suspension was used to inoculate each tube.

Preparation of plates. For the cup plate assays and the bioautography, large plates were used, each containing $150 \mathrm{ml}$ of agar medium inoculated with the test organism. Each plate consisted of a chromium-plated brass frame, $20 \times 40 \mathrm{~cm}$, laid between two sheets of $3 \mathrm{~mm}$ thick glass. The plates were sterilized in a drying oven. For each plate, $150 \mathrm{ml}$ of single strength medium together with $3.0 \mathrm{~g}$ Bacto agar (Difco) in a $500 \mathrm{ml}$ flask was sterilized by autoclaving for $10 \mathrm{~min}$ at $120^{\circ} \mathrm{C}$. The flasks were then placed in a water bath thermostated at $47^{\circ} \mathrm{C}$ for $0.5-1 \mathrm{~h}$. The contents of each flask were mixed with $5 \mathrm{ml}$ of washed and optically standardized inoculum (see above) and then poured into the plate and allowed to cool. Before pouring the agar media, the plates had been placed on a carefully levelled surface (using oil levels) in order to obtain a uniform thickness in the agar layer.

Cup plate assays. For the cup plate assays, $60-80$ cups, $6 \mathrm{~mm}$ in diameter were bored in the solid agar medium of each plate. In laboratory $I$, a specially designed apparatus for making the cups was used. ${ }^{30}$ Standard and test solutions in $0.03 \mathrm{ml}$ aliquots were pipetted into the cups. In order to minimize the effect of time ${ }^{31}$ on the assay results (i.e. to reduce the tendency of those solutions first applied to give larger zones than those last applied), the cups in each plate were filled in the shortest time possible and the plate was then left at room temperature for at least $10-15 \mathrm{~min}$ prior to incubation at $37^{\circ} \mathrm{C}$. An experienced worker can fill the cups of one plate in $10-15 \mathrm{~min}$. After incubation overnight at $37^{\circ} \mathrm{C}$ in a thermostated room, the diameters of the growth zones were measured.

The following concentrations of niacin standard were used: in laboratory $\mathrm{I}, 0.05,0.1$, $0.3,1$, and $3 \mu \mathrm{g}$ per ml and, in laboratory II, $0.1,0.3,1,3$, and $10 \mu \mathrm{g}$ per ml. At least four cups per plate were used for each standard concentration. The twenty standard cups were spread over the plate in a systematic way in order to eliminate the effect of variations in the thickness of the agar layer.

The algal extracts were assayed undiluted and at two different dilutions in laboratory I. In laboratory II only undiluted extracts were assayed. At least three cups per plate were used for each concentration of extract.

Both laboratories normally used plates with 68 cups. Since twenty cups were used for the standards, the remaining 48 cups could be used for the assay of 16 different test solutions. The growth zones were measured to the nearest $0.5 \mathrm{~mm}$ with a transparent ruler.

Bioautography. For bioautography, paper chromatography by means of the descending technique was carried out on large sheets $(19 \times 57 \mathrm{~cm})$ of Whatman No. 1 filter paper whereby $6-8$ samples could be run simultaneously. The chromatograms were run in a mixture of $i s o$ propanol-water $(75: 25 \mathrm{v} / \mathrm{v})$ at $21^{\circ} \mathrm{C}$. When the solvent front had advanced to about $40 \mathrm{~cm}$ from the starting line, the chromatograms were dried in a stream of warm air and cut to fit the agar plates. The dried chromatograms were placed on $L b$. arabinosus plates, and the plates were incubated overnight at $37^{\circ} \mathrm{C}$. S. faecalis plates can also equally well be used. ${ }^{32}$

Usually $1-5 \mu \mathrm{l}$ of each algal extract - applied as a small spot - was used for the bioautographic investigation. Niacin and niacinamide were employed as standards and had $R_{F}$ values of 0.46 and 0.70 , respectively, in the solvent system used. As little as $0.03-$ $0.05 \mu \mathrm{g}$ of either niacin or niacinamide could be easily detected bioautographically.

For the bioautographic detection of "bound" niacin, the following procedure was used: After the paper chromatogram was run in the isopropanol-water mixture and dried, the upper part was sprayed with conc. ammonia. While still wet, it was laid between two

Acta Chem. Scand. 15 (1961) No. 4 
glass plates and placed in a drying oven at $50^{\circ} \mathrm{C}$ for $10 \mathrm{~min}$. The chromatogram was then dried in a stream of warm air and developed on a $L b$. arabinosus plate.

Tube assays. A final volume of $10 \mathrm{ml}$ per tube was used. For information about test tubes, turbidity measurements and instruments, see section entitled "Measurement of bacterial growth in the tubes". A $5 \mathrm{ml}$ aliquot of standard or sample was added to the test tubes, followed by $5 \mathrm{ml}$ of double strength medium and a glass bead. The tubes were then covered (see below) and sterilized by autoclaving at $120^{\circ} \mathrm{C}$ for $5 \mathrm{~min}$. After cooling to room temperature under running tap water and inoculating (see above), the tubes were incubated at $37^{\circ} \mathrm{C}$ in a thermostated water bath. Both laboratories used an incubation time of $24-26 \mathrm{~h}$ for the $L b$. arabinosus and $L b$. casei tube assay. For $S$. faecalis, an incubation time of $18-22 \mathrm{~h}$ was used in laboratory $\mathrm{I}$ whereas $30-36 \mathrm{~h}$ was used in labora. tory II due to the somewhat slower growth.

In laboratory $I$, the test tubes were covered with aluminium caps. To four series of tubes, standard niacin solution was added to give the following amounts of niacin per tube: $0,0,01,0.025,0.05$, and $0.1 \mu \mathrm{g}$. In laboratory II, the test tubes in each rack were covered with a metal cover lined with a thick layer of cotton. To six series of tubes, standard solution was added to give the following amounts of niacin per tube: $0,0.02,0.04,0.06$, 0.10 , and $0.20 \mu \mathrm{g}$.

In both laboratories, the test extracts were, after appropriate dilution, set up in triplicate and each assay was carried out at three concentration levels. Uninoculated tubes containing distilled water and medium were used as blanks.

For cleaning the test tubes, a washing powder consisting of polymer phosphates and neutral surface active agents was used. When a tube series was finished, the tubes were emptied and rinsed twice with tap water. After soaking overnight in a solution of the washing powder, the tubes were cleaned by means of a brush and rinsed several times with tap water followed by one rinsing with distilled water. The tubes were than filled with distilled water, autoclaved at $120^{\circ} \mathrm{C}$ for $10 \mathrm{~min}$, emptied and rinsed twice with distilled water and finally dried overnight in an oven.

\section{RESULTS AND DISCUSSION}

Extraction procedures for niacin. The extraction of niacin from natural materials generally offers little difficulty because of the stability of this compound. The extraction procedures mostly used involve autoclaving the finely divided sample for $15-30 \mathrm{~min}$ at $120^{\circ} \mathrm{C}$ in either $\mathrm{N}$ sulfuric acid $4,7,8,12,16,21$ or $\mathrm{N}$ hydrochloric acid $2,5,17$. Of the several extraction procedures tested by Ericson in his investigation on the determination of niacin in marine algae, autoclaving in $\mathrm{N}$ sulfuric acid for $\mathrm{l} \mathrm{h}$ at $120^{\circ} \mathrm{C}$ was found to be the best ${ }^{1}$.

In the preliminary experiments of this investigation, the $S$. faecalis cup plate method was used as assay procedure for establishing the most favourable conditions for the extraction of niacin from algal samples. In order to ascertain the completeness of the extraction, we first of all compared autoclaving in $\mathrm{N}$ and $3 \mathrm{~N}$ sulfuric acid for $\mathrm{I} \mathrm{h}$ at $120^{\circ} \mathrm{C}$ and found that $3 \mathrm{~N}$ acid gave $20-50 \%$ higher niacin assay values than did $\mathrm{N}$ acid. We also compared autoclaving in $3 \mathrm{~N}$ sulfuric acid at $120^{\circ} \mathrm{C}$ for $0.5 \mathrm{~h}$ and for $1 \mathrm{~h}$, and found that in some instances somewhat higher niacin assay values were obtained with the longer autoclaving time. Extracting the same sample twice with $3 \mathrm{~N}$ sulfuric acid for $1 \mathrm{~h}$ at $120^{\circ} \mathrm{C}$ revealed that the second extract contained less than $5 \%$ of the amount of niacin found in the first one. The extraction procedures finally chosen involved autoclaving the samples with $\mathrm{N}$ or $3 \mathrm{~N}$ sulfuric acid for $1 \mathrm{~h}$ at $120^{\circ} \mathrm{C}$ (for details, see Experimental).

Cup plate assays for niacin. Plate assays for the microbiological determination of niacin with $L b$. arabinosus as the test organism have been published 
by Ericson ${ }^{1}$, Morris and Jones ${ }^{17-18}$, Simpson ${ }^{19,20}$, Karkun and $\mathrm{De}^{21}$ and Kojima et al. ${ }^{22-25}$. The three major variants of the plate assay method ${ }^{26}$ have been used, viz. the cup plate method ${ }^{1,17-20}$, the cylinder plate method ${ }^{21}$ and the paper disc method ${ }^{22-25}$. Although the use of large plates instead of petri dishes has the advantage of improved precision and increased through-put of samples ${ }^{19,20,26,31}$, only Ericson ${ }^{1}$ and Simpson ${ }^{19,20}$ have employed large plates for the microbiological assay of niacin. Kojima et al. ${ }^{22-25}$ have performed a very thorough investigation of the paper disc method for the microbiological determination of niacin as well as several other B-vitamins and amino acids. ${ }^{22-25}$ They also used $L b$. casei and $L$. mesenteroides as test organisms in the plate assay for niacin but found $L b$. arabinosus to be superior.

We started with $L b$. arabinosus as the test organism in the cup plate assay for niacin and employed the acetate medium (Table 2). However, we did not find this method to be sufficiently reliable and sensitive. Only occasionally were good cup plates with well defined growth zones obtained, although several variations in the assay medium and the inoculum were tried. The lowest standard concentration that gave readable growth zones was 0.5 or $1.0 \mu \mathrm{g}$ of niacin per $\mathrm{ml}$ which is in agreement with the findings of previous workers ${ }^{17}, 19,22-25$. We also tested $L b$. casei ATCC 7469, Lb. fermenti ATCC 9338 and $L$. mesenteroides ATCC 9135 with the acetate medium but without success. Lb. fermenti at first seemed very promising since zones of heavy growth were obtained in clear plates without any background growth. However, the edges of the dense growth zones were always too fuzzy for accurate work.

The cup plate assay for niacin with $\mathrm{S}$. faecalis. In laboratory I, S. faecalis ATCC 8043 had been used for several years in the cup plate assay and bioautography of folic and folinic acid factors ${ }^{33-35}$. Tube assays for niacin with $S$. faecalis had been suggested earlier in the literature ${ }^{36,37}$. We therefore decided to try this test organism in the cup plate assay for niacin. With the citrate medium given in Table 2, $S$. faecalis never failed to give very good, sensitive and reproducible cup plate assays. In the concentration range of 0.05 to $100 \mu \mathrm{g}$ of niacin per $\mathrm{ml}$, well defined zones of dense growth were obtained. In Fig. 1, the mean values for the diameters of the growth zones obtained from ten arbitrarily chosen plates from each laboratory are plotted against the logarithm of the standard concentration. As can be seen, the straight-line relationship between the logarithm of the concentration and the mean zone diameter norm-

Fig. 1. Growth response of $S$. faecalis to niacin in the cup plate assay method; - standard of Laboratory I; $O$ standard of Laboratory II.

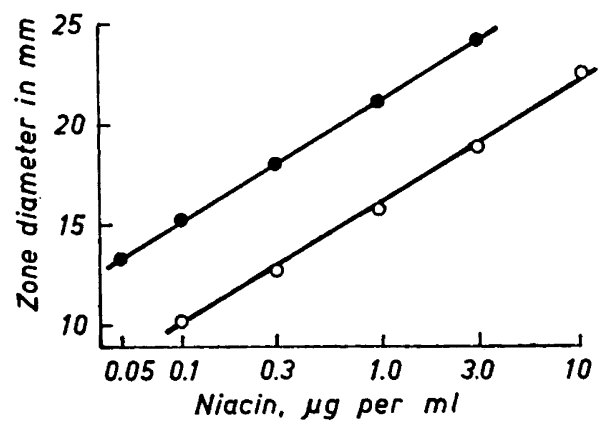

Acta Chem. Scand. 15 (1961) No. 4 
ally found in plate assays ${ }^{26,31}$ was obtained in both laboratories for the niacin standards. For the same concentration, the growth zones obtained in laboratory I were about $5 \mathrm{~mm}$ larger than those in laboratory II. This is due to the lighter inoculum used for preparing the $S$. faecalis plates in laboratory I since, for a given standard concentration, the size of the growth zone is inversely related to the density of the plate inoculum ${ }^{31}$.

The growth zones were measured to the nearest $0.5 \mathrm{~mm}$ with a transparent ruler. The mean value of the zone diameters from cups with identical solutions was calculated to the nearest $0.1 \mathrm{~mm}$. The niacin assay value for each algal sample, obtained from each plate, was calculated to the nearest $\mu \mathrm{g}$. This was also the case when several dose levels of the same algal extract were assayed simultaneously with the undiluted extract on the same plate. Some investigators recommend the reading of the zone diameters to the nearest $0.1 \mathrm{~mm}$ with slide calipers modified by the addition of needle points ${ }^{19,31,38}$. We also tested this measuring procedure but, apart from being more time consuming, we found that it did not significantly alter the assay results. Furthermore, the sharpness of the niacin growth zones could not justify a more precise measurement than to the nearest $0.2 \mathrm{~mm}$.

The sensitivity of our $S$. faecalis plate method is about ten times higher than that of the plate methods with $L b$. arabinosus previously described ${ }^{17},{ }^{19}, 22-25$. Thus, with the techniques used in both laboratories, the lower assay limit for the cup plate method corresponded to $2-3 \mu \mathrm{g}$ of niacin per g dry weight of the test material.

The reproducibility of the cup plate assay for niacin with $S$. faecalis as test organism compares favourably with that usually obtained in plate assays of growth factors, viz. $\pm 15-20 \%{ }^{26}$. Both laboratories made three extracts (one with $\mathrm{N}$ and two with $3 \mathrm{~N}$ sulfuric acid) of each of the eight algal samples listed in Table 1. A detailed record of the cup assays for three of the algal samples (18 extracts) is given in Table 4 and a summarized record for all algal samples in Table 7. A very good agreement was obtained between the assays carried out in both laboratories as well as between the two $3 \mathrm{~N}$ sulfuric acid extracts prepared from each sample. In order to obtain a reliable determination of niacin, we employed a minimum of three separate cup plate assays, made on three different days, for each extract. As a rule, each extract was assayed with $5-6$ plates in laboratory I and with $3-5$ plates in laboratory II (Tables 4, 6, and 7 ). Of the about 220 separate assay values obtained for the 48 algal extracts, made in both laboratories, there were only ten instances where the separate assay values differed from the mean assay value of the extract in question by $\pm 20-25 \% ; 18$ separate assay values were found to differ by $\pm 15-20 \%$ whereas the remaining 190 assay values differed by less than $\pm 15 \%$.

The validity of the cup plate assay method for niacin with $S$. faecalis was investigated by recovery tests (see Table 6). Recoveries of $90-100 \%$ were obtained.

When assaying for niacinamide in the $S$. faecalis plates, zones of dense growth were obtained but the edges were very fuzzy and ill-defined. Mixtures of niacin and niacinamide also gave ill-defined growth zones. The reason for this is not known. The appearance of the growth zones in the cup plate assay 
Table 4. Reproducibility of the cup plate assay for niacin with $S$. faecalis. The assay values are given as $\mu \mathrm{g}$ niacin per $\mathrm{g}$ dry weight.

\begin{tabular}{|c|c|c|c|c|c|}
\hline $\begin{array}{c}\text { Algal } \\
\text { sample }^{a}\end{array}$ & $\begin{array}{l}\text { Sulfuric } \\
\text { acid } \\
\text { used for } \\
\text { extraction }\end{array}$ & Separate assay values & $\begin{array}{l}\text { Mean } \\
\text { value }\end{array}$ & Separate assay values & $\begin{array}{l}\text { Mean } \\
\text { value }\end{array}$ \\
\hline \multirow[t]{3}{*}{ Fs 1} & $\mathrm{~N}$ & $\begin{array}{lllll}18 & 14 & 20 & 15 & 15\end{array}$ & 16.4 & $\begin{array}{lllll}14 & 14 & 16 & 19 & 19\end{array}$ & 16.4 \\
\hline & $3 \mathrm{~N}$ & $\begin{array}{llllll}20 & 23 & 23 & 25 & 25 & 22\end{array}$ & 23.0 & $22 \quad 22 \quad 25$ & 23.0 \\
\hline & $3 \mathrm{~N}$ & $\begin{array}{lllll}23 & 20 & 22 & 20 & 18\end{array}$ & 20.6 & 192121 & 20.3 \\
\hline \multirow[t]{3}{*}{$\operatorname{Lh}:$} & $\mathrm{N}$ & $\begin{array}{lllll}11 & 10 & 10 & 13 & 10\end{array}$ & 10.8 & $\begin{array}{llll}9 & 11 & 11 & 12\end{array}$ & 10.8 \\
\hline & $3 \mathrm{~N}$ & $\begin{array}{lllll}11 & 16 & 17 & 13 & 11\end{array}$ & 13.6 & $\begin{array}{lllll}11 & 12 & 13 & 14 & 13\end{array}$ & 12.6 \\
\hline & $3 \mathrm{~N}$ & $\begin{array}{lllll}15 & 12 & 12 & 12 & 11\end{array}$ & 12.4 & $\begin{array}{lll}13 & 13 & 17\end{array}$ & 14.3 \\
\hline \multirow[t]{3}{*}{$\mathrm{Rp} 1$} & $\mathrm{~N}$ & $\begin{array}{lllll}19 & 18 & 18 & 21 & 19\end{array}$ & 19.0 & $\begin{array}{llllll}20 & 18 & 17 & 20 & 21 & 21\end{array}$ & 19.5 \\
\hline & $3 \mathrm{~N}$ & $\begin{array}{llllll}24 & 26 & 28 & 25 & 26 & 24\end{array}$ & 25.5 & $\begin{array}{llll}26 & 28 & 28 & 30\end{array}$ & 28.0 \\
\hline & $3 \mathrm{~N}$ & $\begin{array}{lllll}23 & 21 & 21 & 27 & 23\end{array}$ & 23.0 & $\begin{array}{lll}26 & 27 & 29\end{array}$ & 27.3 \\
\hline
\end{tabular}

a See Table 1.

b In both laboratories two extracts were made with $3 \mathrm{~N}$ sulfuric acid, and the assay values for each extract are recorded separately. Only one extract was made with $\mathrm{N}$ sulfuric acid.

c Each assay value recorded was obtained from a separate plate.

could, within certain limits, be used as a check of the bioautography results for the presence or absence of niacinamide in the test preparations. The algal extracts prepared for bioautographic tests (extraction with $0.1 \mathrm{~N}$ sulfuric acid) and shown to contain mainly niacinamide, all gave ill-defined growth zones in the cup plates. Thus, in order to be able to use $S$. faecalis in the cup plate assay for niacin, the samples must be hydrolyzed so that they contain only niacin. This condition is easily fullfilled by the use of $\mathrm{N}$ or $3 \mathrm{~N}$ sulfuric acid for the extraction. In these extracts, only niacin was found by bioautography.

In laboratory I, severe infections of the S. faecalis plates sometimes occurred. All work with $S$. faecalis plates (citrate medium) was therefore carried out in a sterile room and special care was taken to avoid infection of the plates. This difficulty was not met with in laboratory II. No similar difficulties were experienced in either laboratory when using $L b$. arabinosus plates (acetate medium) for bioautography. No infection occurred within the first $24 \mathrm{~h}$ and these plates could therefore be used and handled anywhere in the laboratories without any special precautions. This is also the case with other acetate medium plates used for cup plate assays and bioautography with other test organisms, e.g. Lactobacillus leichmannii 313 ATCC 7830 used for vitamin $\mathrm{B}_{12}$ (factors), deoxyribonucleosides and deoxyribonucleotides, and Pediococcus cerevisiae ATCC 8081 used for folinic acid factors and thymidine ${ }^{35,39}$.

Tube assays for niacin. The most commonly used assay method for the microbiological determination of niacin is the tube assay method with $L b$. 
arabinosus ATCC 8014 as the test organism ${ }^{2-8}$, and this method has also reached an official status in some countries ${ }^{2,4,7,8}$. Tube assay methods for niacin with Lb. casei ATCC $7469^{9-13}$, L. mesenteroides ATCC 9135 ${ }^{14-16}$, and S. faecalis ATCC $6057^{40}$ have been published but these have not been investigated so thoroughly as the assay with $L b$. arabinosus. $S$. faecalis ATCC 8043 has also been suggested for use as test organism in tube assays for niacin ${ }^{36,37}$ and standard curves (or tables) were given, but this assay method has never been tested in practice.

Since a reliable cup plate assay method for niacin with $S$. faecalis could be developed, we also wanted to test this organism in the tube assay for niacin. In this investigation, both laboratories have assayed a certain number of algal samples (see Table 1) for niacin with the $S$. faecalis cup plate assay method and with the $S$. faecalis turbidimetric tube assay method, and these two assay methods have been compared with the $L b$. arabinosus turbidimetric tube assay procedure. Moreover, in an investigation performed on some other algal samples, a comparison was made between the niacin assay values obtained by the turbidimetric tube assay method with $L b$. arabinosus, $L b$. casei and $S$. faecalis.

The dose response curves obtained with $L b$. arabinosus and $S$. faecalis are given in Fig. 2. The percent light transmittance readings in each response curve were obtained from ten arbitrarily chosen tube series. The relatively high blank of $83 \%$ light transmittance obtained in the Lb. arabinosus assay in laboratory $\mathrm{I}$ is in agreement with the findings of Loy et al. ${ }^{41}$ They obtained a blank of $80 \%$ light transmittance and found that, in turbidimetric tube assays, more growth occurred in the blanks for the niacin assays than in the assays of other B-vitamins.

The duration of the incubation period used for the different test organisms was determined by the time required for the tube series to obtain maximum turbidity. That maximum turbidity had been reached was proved by the observation that no significant increase occurred during an additional two hour period of incubation in the tubes containing the highest level of standard vitamin solution ${ }^{41-43}$. The niacin assay value obtained for each extract in a tube assay was calculated to the nearest $0.5 \mu \mathrm{g}$ per g dry weight (see Table 5).

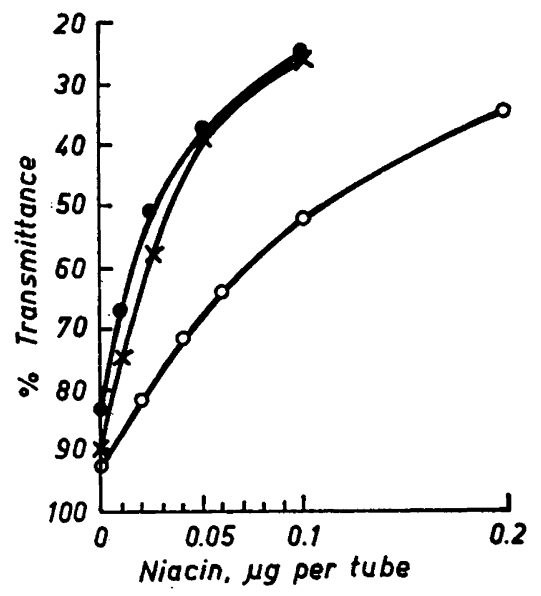

Fig. 2. Growth response of $L b$, arabinosus and $S$. faecalis to niacin in turbidimetric tube assays; $L b$. arabinosus standard curve of Laboratory I; O Lb. arabinosus standard curve of Laboratory II; $\times S$. faecalis standard curve of Laboratory I.

Acta Chem. Scand. 15 (1961) No. 4 
Table 5. Reproducibility of the turbidimetric tube assay method for niacin with $S$. faecalis and $L b$. arabinosus. The assay values are given as $\mu$ g niacin $\mu e r \mathrm{~g}$. dry weight. The extracts were made by autoclaving in $3 \mathrm{~N}$ sulfuric acid for $1 \mathrm{~h}$ at $120^{\circ} \mathrm{C}$ a

\begin{tabular}{|c|c|c|c|c|c|}
\hline \multirow{2}{*}{$\begin{array}{c}\text { Algal } \\
\text { sampleb }\end{array}$} & \multirow{2}{*}{$\begin{array}{c}\text { Test } \\
\text { organism }\end{array}$} & \multicolumn{2}{|l|}{ Laboratory I } & \multicolumn{2}{|l|}{ Laboratory IJ } \\
\hline & & Separate assay values & $\begin{array}{l}\text { Mean } \\
\text { value }\end{array}$ & Separate assay values & $\begin{array}{l}\text { Mean } \\
\text { value }\end{array}$ \\
\hline Fs 1 & S. faecalis & $\begin{array}{lll}21.5 & 24.0 & 22.0 \\
21.0 & 19.0 & 18.5\end{array}$ & $\begin{array}{l}22.5^{\mathrm{a}} \\
19.5^{\mathrm{a}}\end{array}$ & $23.021 .5 \quad 21.0$ & $21.8^{\mathrm{c}}$ \\
\hline $\operatorname{Lh} 2$ & & $\begin{array}{rrr}11.0 & 12.5 & 9.5 \\
11.0 & 10.5 & 13.5\end{array}$ & $\begin{array}{l}11.0 \\
11.7\end{array}$ & $\begin{array}{lll}12.0 & 10.5 & 10.5\end{array}$ & $11.0^{\mathrm{c}}$ \\
\hline $\mathrm{Rp} 1$ & & $\begin{array}{lll}22.5 & 25.0 & 21.5 \\
22.0 & 24.0 & \\
\end{array}$ & $\begin{array}{l}23.0 \\
23.0\end{array}$ & $25.523 .5 \quad 26.0$ & $25.0^{\mathrm{c}}$ \\
\hline Fs 1 & $L b . a r a b$. & $\begin{array}{lll}23.5 & 23.0 & 21.0 \\
23.0 & 23.0 & 25.5\end{array}$ & $\begin{array}{l}22.5 \\
23.8\end{array}$ & $\begin{array}{ll}31.0 & 29.0 \\
27.0 & 26.0\end{array}$ & $\begin{array}{l}30.0 \\
26.5\end{array}$ \\
\hline $\operatorname{Lh} 2$ & & $\begin{array}{llll}13.5 & 15.0 & 14.5 \\
12.0 & 15.0 & 13.5\end{array}$ & $\begin{array}{l}14.3 \\
13.5\end{array}$ & $\begin{array}{ll}15.5 & 15.5 \\
16.0 & 15.0\end{array}$ & $\begin{array}{l}15.5 \\
15.5\end{array}$ \\
\hline Rp 1 & & $\begin{array}{lll}28.0 & 21.5 & 26.0 \\
25.0 & 24.5 & 28.0\end{array}$ & $\begin{array}{l}25.2 \\
25.8\end{array}$ & $\begin{array}{ll}30.0 & 30.5 \\
27.0 & 28.0\end{array}$ & $\begin{array}{l}30.3 \\
27.5\end{array}$ \\
\hline
\end{tabular}

a In both laboratories two extracts were made with $3 \mathrm{~N}$ sulfuric acid, and the assay values for each extract are recorded separately.

b See Table 1 .

c Only one of the two extracts was assayed by the S. faecalis tube method in Laboratory II.

A detailed record of the tube assays for three of the algal samples is given in Table 5 and a summarized record of all algal samples is shown in Table 7. The assay values given in Tables 6,7 , and 8 are the mean values obtained from two or three separate tube assays. A very good agreement was obtained between the assays carried out in both laboratories as well as between the two $3 \mathrm{~N}$ sulfuric acid extracts prepared from each sample. The reproducibility of the turbidimetric tube assay for niacin with $S$. faecalis and $L b$. arabinosus compares favourably with that usually obtained in tube assays of growth factors, i.e. $\pm 10 \%{ }^{6,27}$. The validity of the tube assays for niacin was also investigated by recovery tests (see Table 6 ). Somewhat lower recoveries were obtained with the $S$. faecalis tube method $(77-89 \%)$ than with the Lb. arabinosus tube method $(85-107 \%)$.

Comparative determinations of niacin carried out by the cup plate method with $\mathrm{S}$. faecalis and by the tube method with $\mathrm{Lb}$. arabinosus and $\mathrm{S}$. faecalis. Comparative niacin assay values obtained by these three assay methods for the eight algal samples are given in Table 7. A very good agreement was obtained between the assays carried out in both laboratories. When comparing the assay values of the $\mathrm{N}$ and $3 \mathrm{~N}$ sulfuric acid extracts of each algal sample obtained with the three assay methods, the following descending order of niacin assay

Acta Chem. Scand. 15 (1961) No. 4 
Table 6. Recovery of niacin added to algal samples. The extracts were made by autoclaving in $3 \mathrm{~N}$ sulfuric acid for $1 \mathrm{~h}$ at $120^{\circ} \mathrm{C}$. The niacin assays were carried out by the cup plate method with $S$. faecalis and by the tube method with Lb. arabinosus and $S$. faecalis.

\begin{tabular}{|c|c|c|c|c|c|c|}
\hline $\begin{array}{c}\text { Extract } \\
\text { No. }^{\mathbf{a}}\end{array}$ & $\begin{array}{c}\text { Algal } \\
\text { sampleb }\end{array}$ & $\begin{array}{c}\text { Addition } \\
\text { of niacin, } \\
\mu \mathrm{g} \text { per } \mathrm{g} \\
\text { sample }\end{array}$ & $\begin{array}{l}\text { Assay } \\
\text { method }\end{array}$ & $\begin{array}{l}\text { Niacin ir } \\
\text { Measured } \\
\text { before } \\
\text { addition } \\
\text { of niacinc }\end{array}$ & $\begin{array}{l}\text { Measured } \\
\text { after } \\
\text { addition } \\
\text { of niacin }\end{array}$ & $\begin{array}{c}\text { Recovery } \\
\%\end{array}$ \\
\hline 1 & An 2 & 10.0 & $\begin{array}{l}\text { S.f. cup } \\
\text { S.f. tube } \\
\text { Lb.arab.tube }\end{array}$ & $\begin{array}{l}9.8 \\
8.2 \\
9.8\end{array}$ & $\begin{array}{l}18.8 \\
16.5 \\
18.2\end{array}$ & $\begin{array}{l}91 \\
83 \\
84\end{array}$ \\
\hline 2 & Fs 1 & 20.0 & $\begin{array}{l}\text { S.f. cup } \\
\text { S.f. tube } \\
\text { Lb.arab.tube }\end{array}$ & $\begin{array}{l}21.8 \\
21.0 \\
23.2\end{array}$ & $\begin{array}{l}41.8 \\
36.3 \\
43.2\end{array}$ & $\begin{array}{r}100 \\
77 \\
100\end{array}$ \\
\hline 3 & $\operatorname{Rp} 2$ & 40.0 & $\begin{array}{l}\text { S.f. cup } \\
\text { S.f. tube } \\
\text { Lb.arab.tube }\end{array}$ & $\begin{array}{l}34.4 \\
35.2 \\
38.5\end{array}$ & $\begin{array}{l}71.3 \\
70.8 \\
76.3\end{array}$ & $\begin{array}{l}92 \\
89 \\
95\end{array}$ \\
\hline $\begin{array}{l}4 \\
5 \\
6\end{array}$ & $\begin{array}{ll}\text { An } 2 \\
\text { Fs } 2 \\
\text { Rp } 2\end{array}$ & $\begin{array}{l}10.0 \\
20.0 \\
35.0\end{array}$ & $\begin{array}{c}\text { Lb.arab.tube } \\
" \\
"\end{array}$ & $\begin{array}{l}11.0 \\
18.2 \\
41.4\end{array}$ & $\begin{array}{l}21.7 \\
38.7 \\
77.3\end{array}$ & $\begin{array}{l}107 \\
103 \\
103\end{array}$ \\
\hline
\end{tabular}

a Extracts No. 1, 2, and 3 were made and assayed in Laboratory I and extracts No. 4, 5, and 6 in laboratory II.

b See Table 1 .

c These assay values are also given in Table 7 .

values was generally obtained: 1) $\mathrm{N}$ sulfuric acid extract assayed by the $L b$. arabinosus tube method, 2) $3 \mathrm{~N}$ sulfuric acid extract assayed by the $L b$. arabinosus tube method, 3) $3 \mathrm{~N}$ sulfuric acid extract assayed by the $S$. faecalis cup method, 4) and 5) $\mathrm{N}$ and $3 \mathrm{~N}$ sulfuric acid extracts assayed by the $S$. faecalis tube method, and 6) $\mathrm{N}$ sulfuric acid extract assayed by the $S$. faecalis plate method.

This study shows that the generally adopted method employing extraction with $\mathrm{N}$ sulfuric acid and assaying with the $L b$. arabinosus tube method gives the highest results also for algal samples. However, for the purpose of assaying a large number of samples, the $S$. faecalis cup method carried out on extracts prepared with $3 \mathrm{~N}$ sulfuric acid can be recommended. The $S$. faecalis cup plate method generally gives $0-20 \%$ lower assay values than the $L b$. arabinosus tube method. Only in one instance, sample Fs 2, was a nearly $40 \%$ lower assay value obtained. Furthermore, control assays with the $L b$. arabinosus tube method on the $3 \mathrm{~N}$ sulfuric acid extracts used in the $S$. faecalis cup method will give assay values $0-10 \%$ lower than those obtained by the best assay method, viz. by the $L b$. arabinosus tube method with $\mathrm{N}$ sulfuric acid extracts. Only for sample Fs 2 was a nearly $20 \%$ lower assay value obtained.

The $S$. faecalis tube method for the assay of niacin in algal samples is hardly of any practical value since the $L b$. arabinosus tube method in most instances 
Table \%. Comparative assays for niacin in algal samples carried out by the cup plate method with $S$. faecalis and by the tube assay method with $L b$. arabinosus and $S$. faecalis. The assay values are given as $\mu \mathrm{g}$ niacin per g dry weight.

\begin{tabular}{|c|c|c|c|c|c|c|c|}
\hline $\begin{array}{c}\text { Algal } \\
\text { sample }\end{array}$ & $\begin{array}{c}\text { Sulfuric } \\
\text { acid } \\
\text { used for } \\
\text { extraction b }\end{array}$ & $\begin{array}{l}\text { L.faecalis } \\
\text { cup }\end{array}$ & $\begin{array}{l}\text { aboratory } \\
\text { S.faecalis } \\
\text { tube }\end{array}$ & $\begin{array}{l}\text { Lb.arab. } \\
\text { tube }\end{array}$ & $\begin{array}{r}\mathrm{I} \\
\underset{\text { cup }}{\text { cuecalis }}\end{array}$ & $\begin{array}{l}\text { aboratory } \\
\text { S.faecalis } \\
\text { tubec }^{c}\end{array}$ & $\begin{array}{l}\text { II } \\
\text { Lb.arab. } \\
\text { tube }\end{array}$ \\
\hline An 1 & $3 \stackrel{\mathrm{N}}{\mathrm{N}}$ & $\begin{array}{l}13.0 \\
15.5\end{array}$ & $\begin{array}{l}13.7 \\
11.7\end{array}$ & $\begin{array}{l}15.3 \\
14.1\end{array}$ & $\begin{array}{l}12.0 \\
15.6\end{array}$ & $\overline{10.3}^{\mathrm{d}}$ & $\overline{15.4}^{\mathrm{d}}$ \\
\hline An 2 & $3 \stackrel{\mathrm{N}}{\mathrm{N}}$ & $\begin{array}{l}6.7 \\
9.8\end{array}$ & $\begin{array}{l}8.0 \\
8.2\end{array}$ & $\begin{array}{r}10.2 \\
9.8\end{array}$ & $\begin{array}{r}6.6 \\
10.3\end{array}$ & $\overline{8.5}$ & $\overline{11.0}$ \\
\hline Fs 1 & $3 \frac{\mathrm{N}}{\mathrm{N}}$ & $\begin{array}{l}16.4 \\
21.8\end{array}$ & $\begin{array}{l}22.0 \\
21.0\end{array}$ & $\begin{array}{l}22.7 \\
23.2\end{array}$ & $\begin{array}{l}16.4 \\
21.7\end{array}$ & $\overrightarrow{21.8}$ & $\overline{28.3}$ \\
\hline Fs 2 & $3 \frac{\mathrm{N}}{\mathrm{N}}$ & $\begin{array}{l}12.8 \\
16.4\end{array}$ & $\begin{array}{l}15.8 \\
13.9\end{array}$ & $\begin{array}{l}22.5 \\
18.5\end{array}$ & $\begin{array}{l}15.5 \\
15.7\end{array}$ & $\overline{14.2}$ & $\overline{18.2}$ \\
\hline $\operatorname{Lh} 1$ & $3 \stackrel{\mathrm{N}}{\mathrm{N}}$ & $\begin{array}{l}14.2 \\
17.3\end{array}$ & $\begin{array}{l}16.7 \\
15.8\end{array}$ & $\begin{array}{l}20.7 \\
20.5\end{array}$ & $\begin{array}{l}11.5 \\
17.5\end{array}$ & $\overline{15.2}$ & $\overline{19.2}$ \\
\hline $\operatorname{Lh} 2$ & $3 \stackrel{N}{N}$ & $\begin{array}{l}10.8 \\
13.0\end{array}$ & $\begin{array}{l}12.5 \\
11.4\end{array}$ & $\begin{array}{l}14.8 \\
13.9\end{array}$ & $\begin{array}{l}10.8 \\
13.5\end{array}$ & $\overline{11.0}$ & $\overline{15.5}$ \\
\hline $\mathrm{Rp} 1$ & $3 \stackrel{N}{N}$ & $\begin{array}{l}19.0 \\
24.3\end{array}$ & $\begin{array}{l}24.2 \\
23.0\end{array}$ & $\begin{array}{l}26.0 \\
25.5\end{array}$ & $\begin{array}{l}19.5 \\
27.7\end{array}$ & $\overline{25.0}$ & $\overline{28.9}$ \\
\hline $\mathrm{Rp} 2$ & $3 \stackrel{N}{N}$ & $\begin{array}{l}29.2 \\
34.4\end{array}$ & $\begin{array}{l}36.8 \\
35.2\end{array}$ & $\begin{array}{l}40.5 \\
38.5\end{array}$ & $\begin{array}{l}32.2 \\
37.2\end{array}$ & $4 \overline{2} .0$ & $\overrightarrow{41.4}$ \\
\hline
\end{tabular}

a See Table 1 .

b In both laboratories two extracts were made with $3 \mathrm{~N}$ sulfuric acid, and the mean value from the assays of these two extracts is given. Only one extract was made with $\mathrm{N}$ sulfuric acid.

c Only one of the two extracts made with $3 \mathrm{~N}$ sulfuric acid was assayed by the $S$. faecalis tube method in Laboratory II.

d The N sulfuric acid extracts were not assayed by the tube method with $S$. faecalis and $L b$. arab. in Laboratory II.

gave considerably higher assay values. Furthermore, a lower recovery was obtained with the $S$. faecalis tube method (Table 6). Upon comparing the cup and tube assay methods with $S$. faecalis, it is seen that, with the $N$ sulfuric acid extracts, the tube method gave higher assay values than the cup method whereas the opposite result was obtained with the $3 \mathrm{~N}$ sulfuric acid extracts. This suggests that the stronger acid liberated substances from the algal samples which interfered in the $S$. faecalis tube method. Morris and Jones ${ }^{17}$ used $\mathbf{N}$ hydrochloric acid for the extraction of niacin from several samples and $L b$. arabinosus as the test organism. They obtained a variable agreement between the niacin assays carried out by the cup plate and tube assay methods and concluded that alterations in the method of extraction are presumably necessary for different materials. The cup plate method gave in most cases lower assay values than the tube method.

Acta Chem. Scand. 15 (1961) No. 4 
Table 8. Comparative assays for niacin in algal samples carried out by the tube assay metod with $L b$, arabinosus, $L b$. casei and $S$. faecalis. The extracts were prepared by autocloaving in $3 \mathrm{~N}$ sulfuric acid for $1 \mathrm{~h}$ at $120^{\circ} \mathrm{C}$. The assay values are given as $\mu \mathrm{g}$ niacin per g dry weight.b

\begin{tabular}{|cc|ccc|}
\hline \multicolumn{2}{|c|}{ Algal sample ${ }^{\mathrm{a}}$} & & \multicolumn{3}{|c|}{ Test organism } \\
& & Lb. arabinosus & Lb. casei & S. faecalis \\
\hline Laminaria hyperborea & $\mathbf{5 / 5 2}$ & 29.0 & 27.5 & $\mathbf{2 4 . 0}$ \\
" & $5 / 53$ & 29.0 & 27.5 & 24.0 \\
" & $\mathbf{4} 55$ & 37.0 & 34.5 & 23.0 \\
Laminaria digitata & $5 / 52$ & 35.0 & 37.5 & 30.0 \\
" & $7 / 52$ & 32.5 & 33.0 & 24.0 \\
Ascophyllum nodosum & $5 / 53$ & 30.0 & 26.5 & 21.5 \\
Fucus serratus & $5 / 52$ & 21.0 & 21.5 & 14.0 \\
Rhodymenia palmata & $4 / 51$ & 83.0 & 59.0 & 45.0 \\
\hline
\end{tabular}

a A separate set of samples, not included in Table 1 .

$b$ Each figure is the mean of at leas ${ }^{+}$two tube assays.

Comparative determinations of niacin carried out by the tube assay method with Lb. arabinosus, Lb. casei and S. faecalis. This comparison was made as a further test of the validity of the $L b$. arabinosus tube assay. A separate set of algal samples, not included in Table 1, was used for this investigation. The results of these comparative assays are given in Table 8 . It will be seen that the results obtained by the tube assay method with $L b$. arabinosus and $L b$. case $i$ agree very closely although the former test organism gave as a rule somewhat higher assay values than the latter. Only in one instance, viz. the red alga Rhodymenia palmata, did the results differ considerably thus indicating the presence of either specific stimulatory or inhibitory substances. Hence, the tube assay values obtained with $L b$. casei on the whole support the validity of the $L b$. arabinosus tube assay values. In accordance with the results obtained above, considerably lower niacin assay values were obtained with the S. faecalis tube method.

Bioautography. In algal extracts used for niacin assays, only niacin was found. In order to avoid deamination of the niacinamide, the extracts for bioautography were prepared by autoclaving in $0.1 \mathrm{~N}$ sulfuric acid (see Experimental). Furthermore, if the algal samples contained any "bound" niacin similar to that occurring in various cereal brans, extraction with $0.1 \mathrm{~N}$ acid would liberate this "bound" niacin without hydrolysing the complex 44-49. Strong acid hydrolysis or treatment with $0.1 \mathrm{~N}$ alkali at room temperature are necessary for the liberation of niacin from "bound" niacin (an alkali-labile complex containing niacin). The "bound" form of niacin is generally a poor source of the vitamin for lactobacilli. Of the lactobacilli used for niacin assays, $L b$. arabinosus can best utilize the "bound" form of niacin from various cereal brans. 44,46,48 Previous investigators have also shown that "bound" niacin does not move on paper chromatograms developed with certain organic solvent systems (mostly mixtures of lower alcohols and water). A chemical spray has been used to locate its position (exposure to $\mathrm{CNBr}$ vapour and spraying with $p$-aminobenzoic acid reagent). ${ }^{46,48,50}$ The possibility that the algal samples 
Table 9. Results of bioautographic studies with Lb. arabinosus as the test organism. Extracts were prepared by autoclaving in $0.1 \mathrm{~N}$ sulfuric acid for $30 \mathrm{~min}$ at $120^{\circ} \mathrm{C}^{\mathrm{a}}$

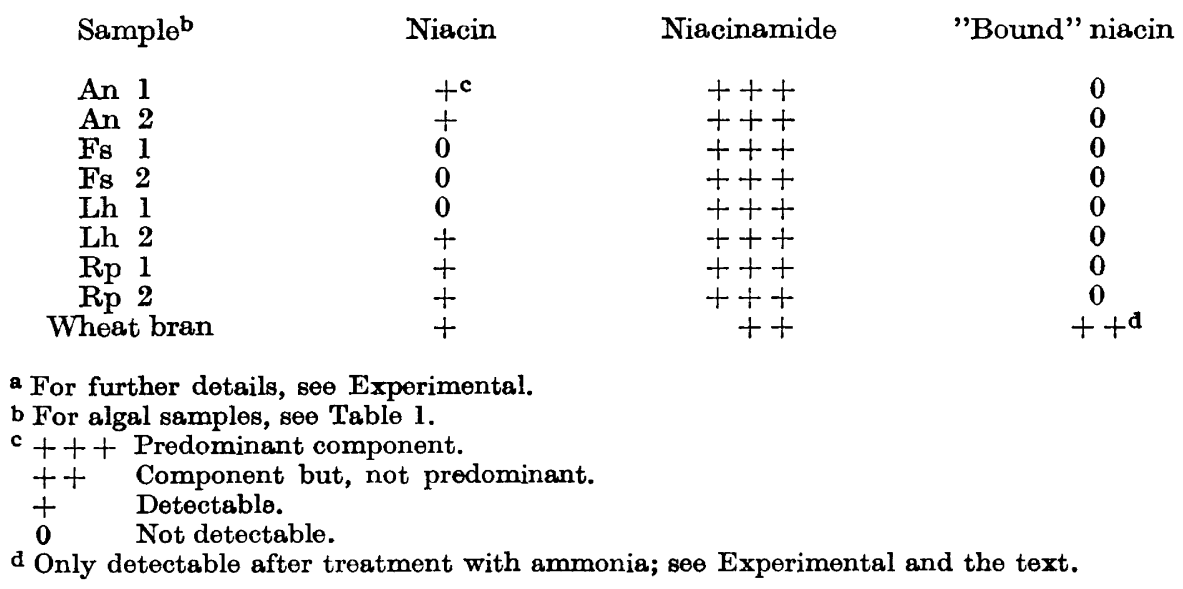

contained "bound" niacin ( $c f$ Refs. ${ }^{6,44}$ ), as is the case with bran from wheat, barley, corn and rice, was excluded by bioautographic tests. In any case, extraction of algal samples with alkali is impracticable because of the highly gelatinous nature of the extracts obtained.

In this investigation, bioautographic studies with $L b$. arabinosus as the test organism were made on extracts of the eight algal samples of Table 1 and on a sample of wheat bran which was used as a source of "bound" niacin. A simple method for the detection of "bound" niacin on paper chromatograms was developed. It involved spraying the upper part of the developed and dried paper chromatogram with conc. ammonia in order to liberate niacin from the "bound" niacin (for details, see Experimental). This method was used to test for the presence of "bound" niacin in the algal samples but the tests were all negative. In the sample of wheat bran as well as in the algal samples, no "bound" niacin was found bioautographically when the spraying with ammonia was omitted.

The results of these bioautographic studies are given in Table 9 . In the algal samples, niacinamide predominated, and traces of niacin were only found in An 1, An 2, and $\operatorname{Lh} 2$. No other active factors were detected in the extracts. The same bioautographic results were obtained in both laboratories.

Acknowledgements. The authors are very grateful to Professor H. Lundin and Dr. L.-E. Ericson for their encouraging interest in this work. Thanks are also due to Mr. D. Knutson, Miss M. Ahrens, and Miss K. Malvig for skilled technical assistance.

\section{REFERENCES}

1. Ericson, L.-E. and Carlson, B. Arkiv Kemi 6 (1953) 511.

2. Analytical Methods Committee, Society of Public Analysts and other Analytical Chemists, Analyst 71 (1946) 397.

3. Snell, E. E. In György, P. (Ed.) Vitamin Methods, Academic Press, Now York 1950, Vol. I, p. 327 .

Acta Chem. Scand. 15 (1961) No. 4 
4. Association of Vitamin Chemists, Methods of Vitamin Assay, 2nd Ed., Interscience, New York 1951, p. 180.

5. Barton-Wright, E. C. The Microbiological Assay of the Vitamin B-Complex and Amino Acids, Sir Isaac Pitman \& Sons, Ltd., London 1952, p. 46.

6. Snell, E. E. In Sebrell, W. H. and Harris, R. S. (Eds.) The Vitamins, Academic Press, Now York 1954, Vol. II, p. 538.

7. National Formulary, 10th Ed., J. B. Lippincott Co., Philadelphia, Pa. 1955, p. 693.

8. Official Methods of Analysis, 8th Ed., Association of Official Agricultural Chemists, Washington 4, D.C. 1955 , p. 826.

9. Landy, M. and Dicken, D. M. J. Lab. Clin. Med. 27 (1942) 1086.

10. Roberts, E. C. and Snell, E. E. J. Biol. Chem. 163 (1946) 499.

11. Clegg, K. M., Kodicek, E. and Mistry, S. P. Biochem. J. 50 (1951) 326.

12. Hoff-Jörgensen, E., Moustgaard, J. and Möller, P. Acta Agr. Scand. 2 (1952) 305.

13. Banerjee, S., Rohatgi, K. and Lahiri, S. Food Research 19 (1954) 134.

14. Johnson, B. C. J. Biol. Chem. 159 (1945) 227.

15. Krehl, W. A., De la Huerga, J., Elvehjem, C. A. and Hart, E. B. J. Biol. Chem. 166 (1946) 53.

16. Gupta, P. N. S. Indian J. Appl. Chem. 21 (1958) 45.

17. Morris, S. and Jones, A. Analyst 78 (1953) 15.

18. Jones, A. Analyst 79 (1954) 586.

19. Simpson, J. S. J. Med. Lab. Technol. 13 (1956) 474.

20. Simpson, J. S. and Harris, D. F. Analyst 82 (1957) 210.

21. Karkun, J. N. and De, S. P. Indian J. Med. Research 40 (1952) 257.

22. Kojima, H., Matsuya, Y., Ozawa, H., Konno, M. and Uemura, T. J. Agr. Chem. Soc. Japan 32 (1958) 33.

23. Kojima, H. and Matsuya, Y. Ibid. 32 (1958) 38.

24. Kojima, H. and Matsuya, Y. Ibid. 32 (1958) 100.

25. Kojima, H. and Matsuya, Y. Ibid. 32 (1958) 189.

26. Gavin, J. J. Appl. Microbiol. 5 (1957) 25.

27. Gavin, J. J. Ibid. 5 (1957) 235.

28. Haug, A. and Larsen, B. Nature 181 (1958) 1225.

29. Larsen, B. Norweg. Inst. Seaweed Research Rept. No. 19 (1958) 13 pp.

30. Callieri, D. A. Acta Chem. Scand. 12 (1958) 2045.

31. Lees, K. A. and Tootill, J. P. R. Analyst 80 (1955) 95.

32. Ovenfors, C. Science Tools 7 (1960) ].

33. Bolinder, A., Widoff, E. and Ericson, L.-E. Arkiv Kemi 6 (1953) 487.

34. Ericson, L.-E. Ibid. 6 (1953) 503.

35. Bolinder, A., Kurz, W. and Lundin, H. J. Inst. Brewing 62 (1956) 497.

36. Luckey, T. D., Briggs, G. M. and Elvehjelm, C. A. J. Biol. Chem. 152 (1944) 157.

37. Rabinowitz, J. C. and Snell, E. E. Ibid. 163 (1947) 631.

38. Harrison, E., Lees, K. A. and Wood, F. Analyst 76 (1951) 696.

39. Bolinder, A. E. and Kurz, W. G. Acta Chem. Scand. 14 (1960) 1173.

40. McCoy, T. A. and Snyder, J. Q. Proc. Oklahoma Acad. Sci. 31 (1950) 100.

41. Loy, H. W., Jr., Parrish, W. P. and Schiaffino, S. S. J. Assoc. Offic. Agr. Chemists 39 (1956) 172 .

42. Ref. 8, p. 837.

43. United States Pharmacopeia, 15th Revision, Mack Publishing Co., Easton, Pa. 1955, p. 888.

44. Sweeney, J. P. and Parrish, W. P. J. Assoc. Offic. Agr. Chemists 37 (1954) 771.

45. Chaudhuri, D. K. and Kodicek, E. Nature 165 (1950) 1022.

46. Reddi, K. K. Ibid. 170 (1952) 745.

47. Guha, B. C. and Das, M. L. Ibid. 180 (1957) 1285.

48. Kodicek, E., Braude, R., Kon, S. K. and Mitchell, K. G. Brit. J. Nutrition 10 (1956) 51.

49. Kodicek, E. and Wilson, P. W. Biochem. J. 76 (1960) 27 P.

50. Kodicek, E. and Reddi, K. K. Nature 168 (1951) 475.

Received December 2, 1960. 